MATEC Web of Conferences 3, 01034 (2013)

DOI: $10.1051 /$ matecconf/20130301034

(C) Owned by the authors, published by EDP Sciences, 2013

\title{
Study of the ternary system water/sodium hydroxide/hydrazine for the extraction of hydrazine
}

\author{
C. Betton, A. El Hajj, D.M. Le, A.J. Bougrine, and H. Delalu \\ Laboratoire Hydrazines et Composés Énergétiques Polyazotés UMR CNRS 5278 "UCBL/CNRS/CNES/SAFRAN- \\ HERAKLES", 22 Av. Gaston Berger, 69622 Villeurbanne Cedex, France
}

\section{Introduction}

The synthesis of hydrazine $\left(\mathrm{N}_{2} \mathrm{H}_{4}\right)$, by the Raschig way, which is used in the field of Aerospace Technology, is carried out in two steps:

- $\quad$ Step 1: formation of monochloramine [1]

(1) $\mathrm{NH}_{3}+\mathrm{OCl}^{-} \rightarrow \mathrm{NH}_{2} \mathrm{Cl}+\mathrm{OH}^{-}$

- Step 2: reaction between monochloramine and ammonia in order to obtain hydrazine [2]

(2) $\mathrm{NH}_{2} \mathrm{Cl}+\mathrm{NH}_{3} \rightarrow \mathrm{N}_{2} \mathrm{H}_{4}+\mathrm{HCl}$

This synthesis requires an excess of the amine reagent, ammonia, compared with the sodium hypochlorite, in order to increase the yield of hydrazine. For the extraction process, the law hydrazine concentrations in the synthesis solutions ( 3 to $4 \%$ weight) impose the preconcentration steps to isolate and purify the final product. The process is based on a liquid-liquid phase separation, generated by the addition of solid sodium hydroxide followed by distillation of organic phase. The ammonia will be recycled and the hydrazine will be purified by fractional crystallization. The optimization of the preconcentration requires the knowledge of phase equilibrium in the quaternary system $\mathrm{H}_{2} \mathrm{O} / \mathrm{N}_{2} \mathrm{H}_{4} / \mathrm{NaOH} / \mathrm{NH}_{3}$. Our study has therefore focused on establishing solid-liquid-liquid isobaric ternary system $\mathrm{H}_{2} \mathrm{O} / \mathrm{N}_{2} \mathrm{H}_{4} / \mathrm{NaOH}$.

In this aim, three isothermal sections (283K, $293 \mathrm{~K}$ and $313 \mathrm{~K}$ ) of the solid-liquid-liquid isobaric ternary system $\mathrm{H}_{2} \mathrm{O} / \mathrm{N}_{2} \mathrm{H}_{4} / \mathrm{NaOH}$ were determined by Isoplethic Thermal Analysis (ITA) [3].

\section{Experimental}

An ITA, original apparatus, developed in our laboratory, was used to study the limit tie lines of the $\mathrm{H}_{2} \mathrm{O} / \mathrm{N}_{2} \mathrm{H}_{4} / \mathrm{NaOH}$ ternary system. It based on the measurement of the thermal effects associated with transformations in the system when its compositions changed.

The ITA device is represented in Figure 1 and 2.

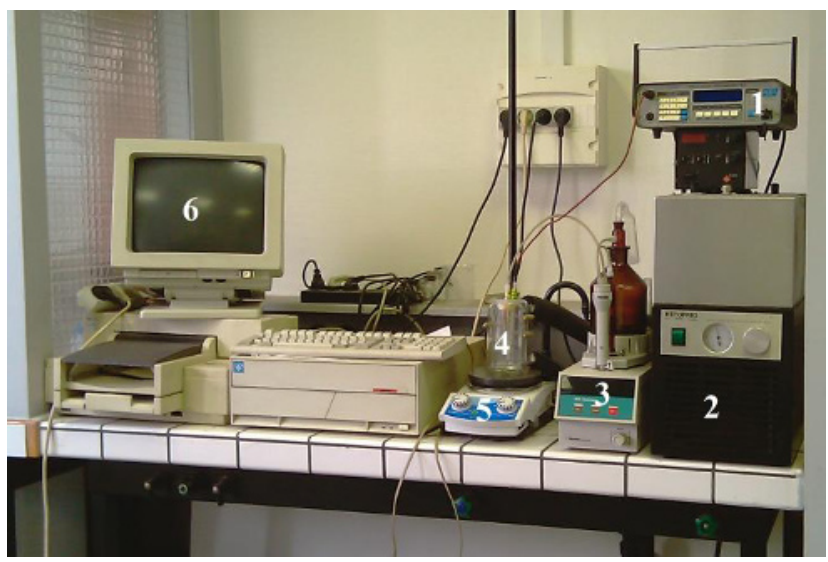

Figure 1. ITA: (1) temperature sensor (precision: 1/1000 K), (2) thermostat, (3) automatic burette, (4) reactor, (5) magnetic stirrer, (6) computer.

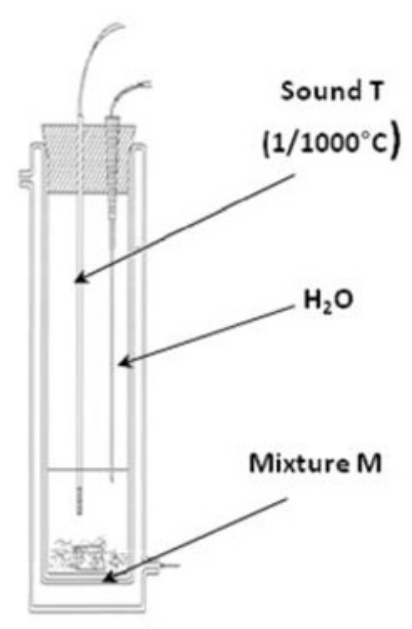

Figure 2. Measuring cell.

The treatment of the data recorded by the ITA device allows to establish the curves of temperature $\mathrm{T}$ as a function of the volume water added. Figure 3 represents a thermogram obtained by ITA for a mixture which global composition $\mathrm{M}$ is located in the biphased domain $\left(\mathrm{L}+\mathrm{NAOH} . \mathrm{H}_{2} \mathrm{O}_{(\mathrm{s})}\right)$, Figure 4. 


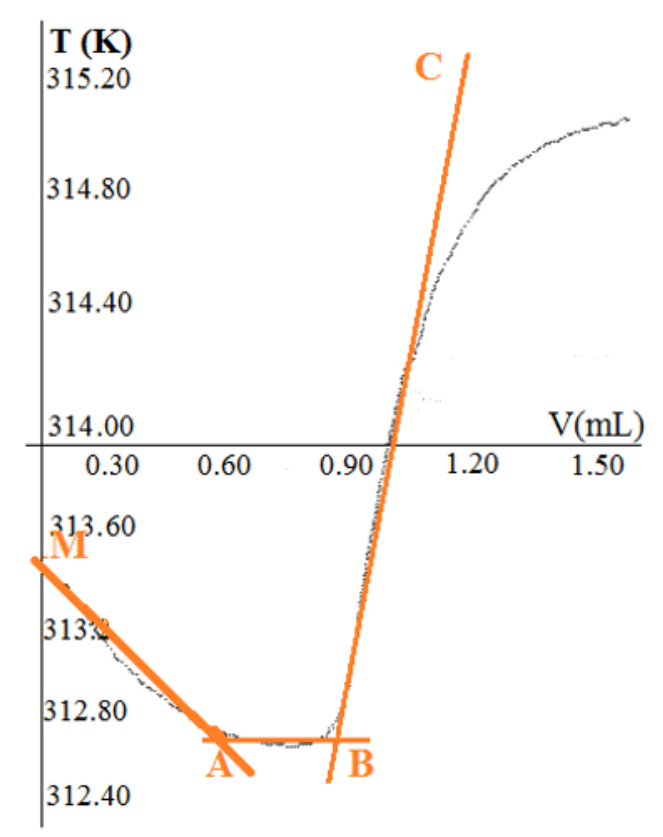

Figure 3. Thermogram, $\mathrm{T}=\mathrm{f}\left(\mathrm{v}_{\mathrm{H} 2 \mathrm{O}}\right)$.

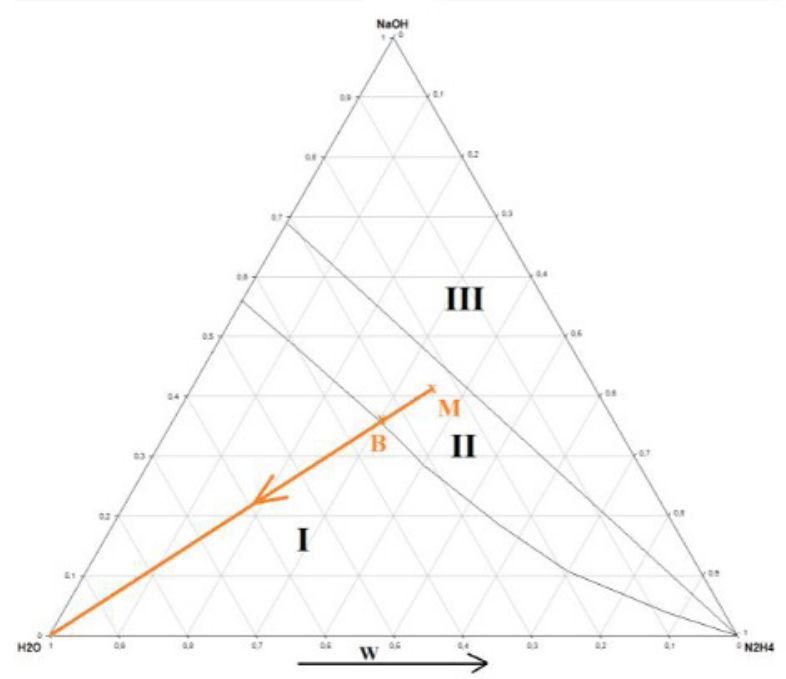

Figure 4. Ternary Diagram.

The endothermic MA segment corresponds to the equilibrium of biphased domains $\left(\mathrm{L}+\mathrm{NaOH} \cdot \mathrm{H}_{2} \mathrm{O}_{(\mathrm{s})}\right)$. AB segment is the dissolution of $\mathrm{NaOH} . \mathrm{H}_{2} \mathrm{O}_{(\mathrm{s})}$. $\mathrm{BC}$ segment is the dilution of the system and the return to the equilibrium temperature. The intersection of the two tangents to the curves on both sides of part B, permits to determine the volume of water added to the mixture and then to deduce the exact global composition of the mixture identified by point $\mathrm{B}$.

\section{Results}

After the determination of the limit of tie line and the data on the solubility of $\mathrm{NaOH}$ in the pure water (binary diagram $\mathrm{H}_{2} \mathrm{O} / \mathrm{NaOH}$ ) [4], we determined the 3 isothermal sections of ternary diagrams at $283 \mathrm{~K}, 293 \mathrm{~K}$ and $313 \mathrm{~K}$. Figure 5 shows the isothermal sections obtained for the $\mathrm{H}_{2} \mathrm{O} / \mathrm{N}_{2} \mathrm{H}_{4} / \mathrm{NaOH}$ ternary system at $283 \mathrm{~K}$.

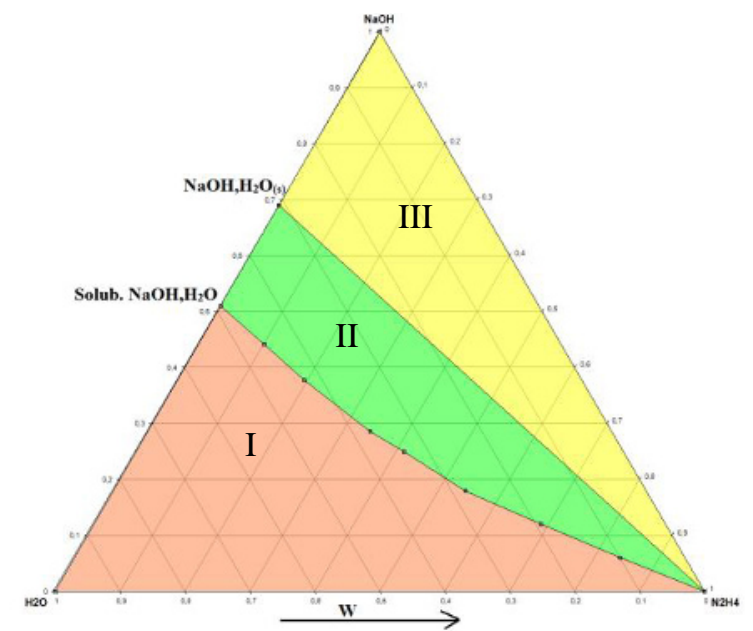

Figure 3. solid-liquid-liquid ternary system $\mathrm{H}_{2} \mathrm{O} / \mathrm{N}_{2} \mathrm{H}_{4} / \mathrm{NaOH}$ at $283 \mathrm{~K}, \mathrm{P}=1$ bar.

The three isotherms (283K, 293K and 313K) are characterized by three domains:

- a liquid monophasic domain in the water rich part

- a biphased domain $\left(\mathrm{L}+\mathrm{NaOH} \cdot \mathrm{H}_{2} \mathrm{O}_{(\mathrm{s})}\right)$

- a triphasic three-phase triangle $\left(\mathrm{NaOH}_{(\mathrm{s})}+\right.$ $\left.\mathrm{NaOH} . \mathrm{H}_{2} \mathrm{O}_{(\mathrm{s})}+\mathrm{N}_{2} \mathrm{H}_{4(\mathrm{l})}\right)$

By comparison the three isotherms, we notice that the biphased domain decreases with the temperature.

\section{Conclusion}

With this results (non demixing at $283 \mathrm{~K}, 293 \mathrm{~K}$ and $313 \mathrm{~K})$, the extraction is not possible. The demixing is observed from $323 \mathrm{~K}$, the optimal conditions were determined $(\mathrm{T}=343 \mathrm{~K})$. At this temperature, we obtain an organic phase of: $5.9 \% \mathrm{w} \mathrm{H}_{2} \mathrm{O}, 90.9 \% \mathrm{w} \mathrm{N}_{2} \mathrm{H}_{4}, 3.2 \% \mathrm{w}$ $\mathrm{NaOH}[5]$.

\section{References}

1. F. Raschig, Z. Angew. Chem. 20206 (1907)

2. E.W. Schmidt, Hydrazine and its Derivatives, Preparation, Properties, Application, $2^{\text {nd }} \mathrm{ed}$, WileyInterscience, New York, 1984

3. J. Berthet, J.J. Counioux. Brevet F9313402, 4 November 1993

4. A. Chretien, R. Kolhmuller, P. Pascal, A.P. Rollet, Nouveau traité de Chimie Minérale, Masson et Cie Editeurs, Paris, 1996

5. R.A. Penneman, L.F. Audrieth, J. Am. Chem. Soc. 71 1644 (1949) 